\title{
Heat Pump Design for Simultaneous Cooling Space and Heating Water Coupled with Earth-Tube Heat Exchanger as Secondary Heat Sink
}

\author{
Weerawoot Arunwattana
}

Department of Physics, Faculty of Science, Mahasarakham University, Mahasarakham 44150, Thailand

(Corresponding author's e-mail: weerawoot.a@msu.ac.th)

Received: 20 October 2020, Revised: 18 May 2021, Accepted: 28 May 2021

\begin{abstract}
A heat pump for simultaneous heating and cooling (HPS) is more efficient in energy and beneficial in use than a reversible heat pump which works in either direction to provide heating or cooling. A HPS is usually coupled with a thermal storage tank for possibly operating in 3 modes: heating mode, cooling mode, and simultaneous heating and cooling mode. To improve the HPS performance in heating mode or cooling mode, the HPS should be installed an auxiliary equipment in order to reject overheat in the system or to absorb supplemental heat into the system. This paper proposed a design of a HPS for cooling space and hot water production coupled with a horizontally shallow earth-tube heat exchanger as secondary heat sink for Thai residences in which the main components in the design are composed of the condenser and the earth tube heat exchanger. The coefficients of performance (COP) of the HPS were evaluated by the experiments. The results showed that it could work the best performance when it worked in simultaneous cooling and heating mode at the water flow rate of $6.0 \mathrm{~L} / \mathrm{min}$ with the coefficient of performance (COP) of $6.3 \pm 3.1 \%$. The HPS had high efficiency and it worked continuously in cooling mode when it operated in the nighttime with the average COP of $4.3 \pm 14.5 \%$. However, an efficiency of the HPS was declined when heat gain in the conditioned room is significantly increased by high intensity of solar radiation in the daytime with the average COP of $2.5 \pm 14.5 \%$.
\end{abstract}

Keywords: Heat pump, Simultaneous heating and cooling, Earth tube heat exchanger, Cooling space, Coefficient of performance

\section{Introduction}

Energy used for cooling or heating systems such as air-conditioning and hot water production is predominantly effect to total energy use in residential sector in many countries including Thailand. Energy consumption in residential sector is third order of energy use in Thailand and the trend of energy use in the past had been increased every year [1]. More than $26 \%$ of total energy in residential sector is used for air conditioners [2]; the air conditioners normally are air-to-air of the vapor compression heat pump system. One appliance coming to be significantly increased is the electrical water heater for shower to relax despite of mostly warm ambient air temperature which one consumes much energy as its energy efficiency is not more than $100 \%$.

To reduce energy consumption in the air-conditioners, many techniques have been done. Due to high ambient air temperature, Arunwattana [3] used the cooling pad to reduce air temperature before cooling in the condenser for hot and humid climate and he found that the average coefficient of performance (COP) of the improved system was $8 \%$ higher than the normal system. Later, this system was also continued to improve efficiency by using drain water leaving from the cooling pad for cooling heat gain in the wall and cooling heat gain on the roof [4]. Further, Arunwattana [5] proposed a horizontal earth-to-air heat exchanger for cooling heat load in the room resulting decreased energy consumption in the air-conditioner. Congedo et al. [6] proposed the use of an air source heat pump system coupled with a horizontal earth-to-air heat exchanger for pre-cooling/heating the air source of the air source heat pump system, reducing the electric power and higher performance compared to the traditional air source heat pump. Enhancing performance of refrigerant cycle in the air conditioner, superheat temperature of the refrigerant before entering to condenser was reduced by cooling water loop [7], increasing thermal performance up to $31 \%$ and by cooling heat pipe heat exchanger [8], increasing thermal performance up to $20 \%$. 
The vapor compression heat pump is widely used for cooling or heating applications as it is very effective in energy use. There are many types of heat pump depending on a type of heat sink/source used. A comprehensive review of the functionalities of the different types of the heat pump can be found in [9]. As a reversible heat pump operates alternatively in heating or cooling, a heat pump for simultaneous heating and cooling (HPS) that can wake under 3 modes: A heating mode, a cooling mode and simultaneous mode is better based on energy efficiency and functionalities. Some authors proposed and investigated heat pumps for simultaneous cooling/heating space and hot water production in buildings [10-12]. Mostly, the thermal storage tank is applied in this system for storing heat; however, the HPS will be reduced in efficiency or shuttled off the system if the water temperature in the storage tank is risk to heat exchange in the condenser (means that the water temperature will be closed to the condensation temperature of the refrigerant resulted in small or no heat exchange). For that reason, an external or a secondary heat sink is required. Generally, a heat sink should be plenty of in the world and have no cost such as ambient air, groundwater, or underground. External heat sinks mostly used in the HPS were reviewed by Bertagnolio and Stabat [13]. In this paper, design and experiment of a HPS for cooling space and hot water production coupled with thermal storage tank and a horizontally shallow earth-tube heat exchanger as secondary heat sink were proposed for Thai residences.

\section{Materials and methods}

\section{Description of the system}

A HPS is presented in Figure 1. Two running modes were assigned namely cooling mode and simultaneous heating and cooling mode. In cooling mode, the air space in the room is cooled by fan coil unit (heat exchange between air and refrigerant in the evaporator: No. 3) while water is heated by condensing unit (heat exchange between water and refrigerant in the condenser: No. 1). The hot water leaving the condenser is then installed in a thermal storage tank and it will be pumped to exchange heat again in the condenser. If the hot water temperature in the tank is risk, the hot water in the tank will be pumped to the horizontally shallow earth-tube heat exchanger (no. 9) for precooling before it is heated again in the condenser. For that reason, the system is capable to operate continuously in the cooling mode and the system does not degrade performance. For simultaneous heating and cooling mode, the air space in the room will be conditioned by the fan coil unit of the HPS; at the same time, the HPS can produce hot water in the condensing unit and it is directly supplied to user.

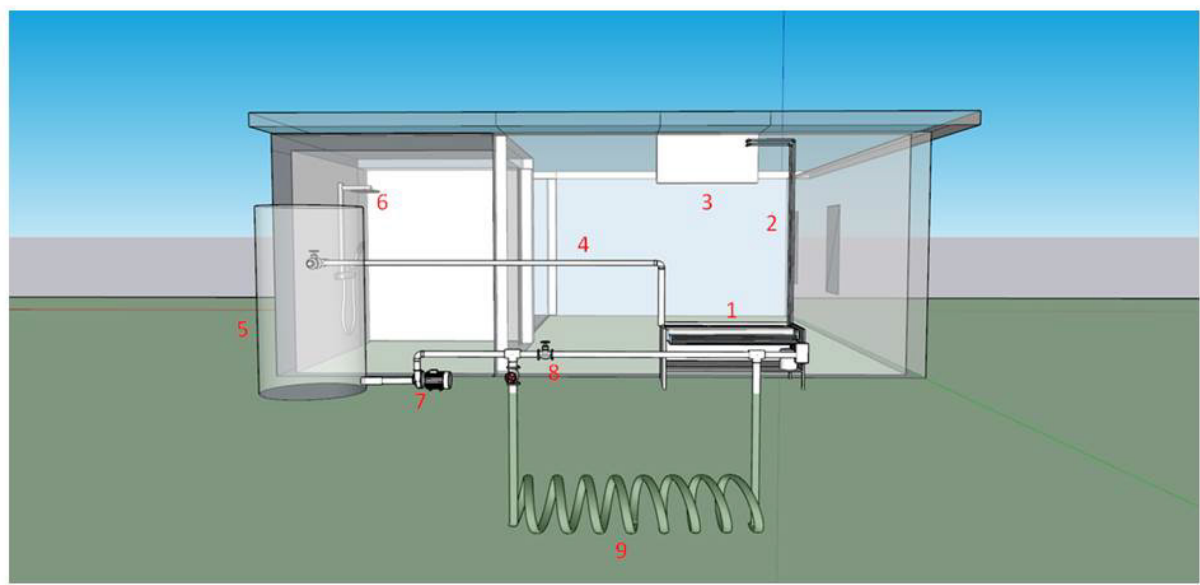

1. Condensing unit 5. Storage water tank

2. Refrigerant flow pipe 6. Shower

3. Fan coil unit

7. Water pump

4. Water flow pipe

8. Valve

9. Earth-tube heat exchanger

Figure 1 Description of the system. 


\section{Design of components in the system}

Two main components: the condenser and the horizontally shallow earth-tube heat exchanger in the system were designed. The design conditions are shown in Table 1. In the above of design conditions, the mass flow rate of refrigerant can be calculated;

$\dot{\mathrm{m}}_{\mathrm{r}}=\frac{\dot{\rho}_{\mathrm{r}, 1} \eta_{\mathrm{v}} \dot{\mathrm{V}}_{\mathrm{C}}}{100}$

where $\dot{\mathrm{m}}_{\mathrm{r}}$ is the mass flow rate of refrigerant $(\mathrm{kg} / \mathrm{s}), \dot{\rho}_{\mathrm{r}, 1}$ is the density of refrigerant $\left(\mathrm{kg} / \mathrm{m}^{3}\right), \eta_{\mathrm{v}}$ is the volume efficiency of compressor (\%), and $\dot{V}_{\mathrm{C}}$ is the swept volume flow rate $\left(\mathrm{m}^{3} / \mathrm{s}\right)$.

The swept volume flow rate depends on the swept volume $\left(\mathrm{V}_{\mathrm{C}}\right)$ and cycle speed (RPM) of compressor as the following equation;

$\dot{\mathrm{V}}_{\mathrm{C}}=\frac{\mathrm{V}_{\mathrm{C}} \times \mathrm{RPM}}{60}$

Table 1 Design conditions.

\begin{tabular}{lc}
\hline Given design parameters & Amount or name \\
\hline Refrigerant & $\mathrm{R}-22$ \\
Evaporation temperature & $7.2^{\circ} \mathrm{C}$ \\
Condensation temperature & $54.4^{\circ} \mathrm{C}$ \\
Amount of super-heating temperature & $2{ }^{\circ} \mathrm{C}$ \\
Amount of sub-cooling temperature & $10^{\circ} \mathrm{C}$ \\
Swept volume of compressor (rotary type) & $30.6 \mathrm{~cm}^{3}$ \\
Cycle speed of compressor & $2820 \mathrm{RPM}$ \\
Inlet water temperature & $30^{\circ} \mathrm{C}$ \\
Outlet water temperature & $45^{\circ} \mathrm{C}$ \\
The soil temperature at $0.5 \mathrm{~m}$ depth & $31^{\circ} \mathrm{C}$ \\
Cooling fraction $(\mathrm{CF})$ & 0.8 \\
\hline
\end{tabular}

\section{Condenser design}

Next, consider condenser design, the heat exchanger is given by tube-in-tube counter flow current heat exchanger assigning the refrigerant flow in the inner tube and the water flow in annulus channel. We consider 3 zones of heat transfer according to refrigerant phase-flow in condenser namely de-superheating zone, condensing zone and sub-cooling zone. Both de-superheating zone and sub-cooling zone is designed by single zone method as the specific heat of refrigerant is almost constant along the path of heat exchange. By contrast, the condensing zone is designed by multi-zones method because the refrigerant flow is 2-phase flow resulting the specific heat is not constant depending on the quality of vapor.

For de-superheating zone, heat transfer rate from the refrigerant line can be determined;

$\dot{\mathrm{Q}}_{\mathrm{d}}=\dot{\mathrm{m}}_{\mathrm{r}}\left(\mathrm{h}_{\mathrm{r}, \mathrm{in}}-\mathrm{h}_{\mathrm{r}, \mathrm{g}}\right)$

where $\dot{Q}_{d}$ is the heat transfer rate in de-superheating zone $(\mathrm{kW}), \mathrm{h}_{\mathrm{r}, \mathrm{in}}$ is the enthalpy of refrigerant at the inlet of condenser $(\mathrm{kJ} / \mathrm{kg})$ and $\mathrm{h}_{\mathrm{r}, \mathrm{g}}$ is the saturated vapor enthalpy of refrigerant $(\mathrm{kJ} / \mathrm{kg})$.

In the above equations, we can calculate heat transfer rate in de-superheating zone and the inlet water temperature $\left(T_{\mathrm{wg}}\right)$ is then determined by the following equation;

$\mathrm{T}_{\mathrm{wg}}=\mathrm{T}_{\mathrm{w}, \mathrm{out}}-\frac{\dot{\mathrm{Q}}_{\mathrm{d}}}{\dot{\mathrm{m}}_{\mathrm{w}} \mathrm{c}_{\mathrm{pw}}}$

where $T_{w, o u t}$ is the outlet water temperature from desuperheating zone $\left({ }^{\circ} \mathrm{C}\right), \dot{\mathrm{m}}_{\mathrm{w}}$ is the water mass flow rate $(\mathrm{kg} / \mathrm{s})$ and $\mathrm{c}_{\mathrm{pw}}$ is the specific heat of water $\left(\mathrm{kJ} / \mathrm{kg}{ }^{\circ} \mathrm{C}\right)$. 
The log mean temperature difference (LMTD) in de-superheating zone is defined;

$$
\text { LMTD }=\frac{\left(T_{r, \text { in }}-T_{w, \text { out }}\right)-\left(T_{C}-T_{w g}\right)}{\ln \frac{\left(T_{r, \text { in }}-T_{w, o u t}\right)}{\left(T_{C}-T_{w g}\right)}}
$$

where $\mathrm{T}_{\mathrm{C}}$ is the condensing temperature of the refrigerant $\left({ }^{\circ} \mathrm{C}\right)$.

Then the product between the overall heat transfer coefficient (U) and heat transfer surface area is then calculated by the following equation;

$\mathrm{UA}=\frac{\dot{\mathrm{Q}}_{\mathrm{d}}}{\mathrm{LMTD}}$

Finally, we can find out the total length of heat exchanger in the de-superheating zone.

$\mathrm{L}_{\mathrm{d}}=(\mathrm{UA})\left[\frac{1}{\pi \mathrm{d}_{1, \mathrm{i}} \mathrm{h}_{\mathrm{rd}}}+\frac{\ln \left(\mathrm{d}_{1, \mathrm{o}} / \mathrm{d}_{1, \mathrm{i}}\right)}{2 \pi \mathrm{k}_{\mathrm{wall}}}+\frac{1}{\pi \mathrm{d}_{1, \mathrm{o}} \mathrm{h}_{\mathrm{wd}}}\right]$

where $L_{d}$ is the total length of heat exchanger in de-superheating zone $(m), d_{1, i}$ is the inside diameter of the inner tube $(m), d_{1, o}$ is the outside diameter of the inner tube $(m), h_{r d}$ is the heat transfer coefficient of refrigerant in de-superheating zone $\left(\mathrm{kW} / \mathrm{m}^{2}{ }^{\circ} \mathrm{C}\right), \mathrm{h}_{\mathrm{wd}}$ is the heat transfer coefficient of water in desuperheating zone $\left(\mathrm{kW} / \mathrm{m}^{2}{ }^{\circ} \mathrm{C}\right)$ and $\mathrm{k}_{\mathrm{wall}}$ is the conductivity of tube wall $\left(\mathrm{kW} / \mathrm{m}{ }^{\circ} \mathrm{C}\right)$.

The heat transfer coefficient of refrigerant in de-superheating zone is determined by Petukhov'equation [14] and the heat transfer coefficient of water in de-superheating zone is determined by Gnielinski's equation [15]. In the sub-cooling zone, the design is similar to the de-superheating zone design. The heat transfer rate in the zone $\left(\dot{\mathrm{Q}}_{\mathrm{s}}\right)$ is calculated from refrigerant line in which we know the inlet and outlet states of refrigerant. Then we can find out the outlet water temperature as we know the given inlet water temperature. Next, the LMTD is determined and finally, the total length of heat exchanger in this zone will be figured out. However, both the heat transfer coefficient for both fluids is determined by Gnielinski's equation.

Multi-zone method is used for designing in condensation zone in which the heat exchanger in this zone will be divided by $\mathrm{N}$ zones and the length $(\Delta \mathrm{L})$ of each zone is identical and it must be defined first. In the assumption, we assume that the pressure drop in each zone will be neglected and temperatures of both fluids in each zone have very small change. The first calculation will be determined the LMTD of zone $i$ as shown in the Eq. (8).

$\mathrm{LMTD}_{\mathrm{i}}=\mathrm{T}_{\mathrm{C}}-\mathrm{T}_{\mathrm{wi}}$

where $\mathrm{T}_{\mathrm{wi}}$ is the water temperature at the zone $i\left({ }^{\circ} \mathrm{C}\right)$. Then the UA of the first zone will be determined by the following equation;

$(\mathrm{UA})_{i}=\frac{1}{\left[\frac{1}{\pi \mathrm{d}_{1} \mathrm{~h}_{\mathrm{r} c, i}{ }^{L L}}+\frac{\ln \left(\mathrm{d}_{1, \mathrm{o}} / \mathrm{d}_{1, \mathrm{i}}\right)}{2 \pi \mathrm{k}_{\mathrm{wall}} \Delta L}+\frac{1}{\pi \mathrm{d}_{1} \mathrm{~h}_{\mathrm{w} c, i} \Delta}\right]}$

where $h_{r c}$ is the heat transfer coefficient of refrigerant in the zone $\left(\mathrm{kW} / \mathrm{m}^{2 \circ} \mathrm{C}\right)$. The heat transfer coefficient of refrigerant in each zone is determined by Dobson \& Chato equation [16] while the heat transfer coefficient of water is determined by the same equation as in the de-superheating zone. For the properties used in the heat transfer equations are depend on the state of the inlet in each zone as representative.

Next, the heat transfer rate in each zone $\left(\dot{Q}_{\mathfrak{i}}\right)$ is calculated by the following equation;

$\dot{\mathrm{Q}}_{\mathrm{i}}=(\mathrm{UA})_{\mathrm{i}} \times \mathrm{LMTD}_{\mathrm{i}}$ 
In above equation, when we start from $i$ equal to 1 (the first zone), $\mathrm{T}_{\mathrm{wi}}$ is equal to $\mathrm{T}_{\mathrm{wg}}$, we can find out the inlet water temperature in zone $i$ for representative of the next zone. We will continually calculate in this step until.

$\sum_{i=1}^{N} \dot{\mathrm{Q}}_{\mathrm{i}}=\dot{\mathrm{Q}}_{\mathrm{c}}=\dot{\mathrm{m}}_{\mathrm{r}}\left(\mathrm{h}_{\mathrm{r}, \mathrm{g}}-\mathrm{h}_{\mathrm{r}, \mathrm{f}}\right)$

where $\dot{Q}_{c}$ is the condensation heat transfer rate and $h_{r, f}$ is the saturated liquid enthalpy. Finally, the numbers of zone will be figured out and the total length of heat exchanger in condensing zone $\left(\mathrm{L}_{\mathrm{C}}\right)$ is then determined;

$\mathrm{L}_{\mathrm{C}}=\mathrm{N} \times \Delta \mathrm{L}$

\section{Earth tube-to-water heat exchanger design}

In the design of the earth tube-to-water heat exchanger, the heat transfer rate of this heat exchanger can be determined by the following equation [5];

$$
\dot{\mathrm{Q}}_{\text {soil }}=\dot{\mathrm{m}}_{\mathrm{w}} \mathrm{c}_{\mathrm{pw}}\left\{\left(\mathrm{T}_{\mathrm{w}, \text { inlet }}-\mathrm{T}_{\text {soil }}\right)+\left(\mathrm{T}_{\text {soil }}-\mathrm{T}_{\mathrm{w}, \text { inlet }}\right) \mathrm{e}^{-\mathrm{L}\left(2 \pi \mathrm{r}_{\mathrm{w}} / \dot{\mathrm{m}}_{\mathrm{w}} \mathrm{c}_{\mathrm{pw}}\right)}\right\}
$$

where $\dot{\mathrm{Q}}_{\text {soil }}$ is the heat transfer rate in the earth tube-to-water heat exchanger $(\mathrm{kW}), \mathrm{T}_{\text {soil }}$ is the soil temperature at the same level as in the earth tube-to-water heat exchanger buried $\left({ }^{\circ} \mathrm{C}\right)$ and $\mathrm{T}_{\mathrm{w} \text {,inlet }}$ is the inlet water temperature in the earth tube-to-water heat exchanger $\left({ }^{\circ} \mathrm{C}\right)$. In the Eq. $(13), \dot{\mathrm{Q}}_{\text {soil }}$ is given by multiplying cooling fraction (CF) in heat transfer rate of condenser as formula;

$\dot{\mathrm{Q}}_{\mathrm{soil}}=\mathrm{CF} \times\left(\dot{\mathrm{Q}}_{\mathrm{d}}+\dot{\mathrm{Q}}_{\mathrm{C}}+\dot{\mathrm{Q}}_{\mathrm{s}}\right)$

The cooling fraction is defined by the following equation;

$\mathrm{CF}=\frac{\dot{\mathrm{Q}}_{\text {soil }}}{\dot{\mathrm{Q}}_{\mathrm{d}}+\dot{\mathrm{Q}}_{\mathrm{C}}+\dot{\mathrm{Q}}_{\mathrm{s}}}$

From the Eq. (13), we can figure out the total length (L) if cooling fraction is given in the design.

\section{Design steps}

According to the given design parameters,

1) Calculate the mass flow rate of refrigerant in Eq. (1) (volume efficiency of compressor is provided by the company depending on the pressure ratio).

2) Calculate the heat transfer rate in the condenser using the refrigerant line and then find the water flow rate by using the energy balance in the condenser.

3) Calculate the total length of the condenser as described in Eqs. (6) - (15) and at this step, the outer tube size will be optimized based on the fixed inner diameter tube and the acceptable water pressure drop.

4) Finally, calculate the tube length of the earth-tube heat exchanger.

In the above of design steps, we get the sizing of condenser and the earth-tube heat exchanger as shown in Table 2.

Note: the length of the ETHE is dependent on the heat rate required to reject in the underground $\left(\dot{\mathrm{Q}}_{\text {soil }}\right)$, inlet water temperature, water mass flow rate, soil temperature, and configuration of the ETHE (effect on heat transfer coefficient) as in Eq. (13). The maximum heat transfer rate in the ETHE can be occurred when the length of the ETHE is very long.

\section{Installation}

The main components of the system (described in Table 2.) were installed and connected in the system as shown in Figure 2. 
Table 2 Technical parameters of the main components in the system.

\begin{tabular}{ll}
\hline Components & \multicolumn{1}{c}{ Details } \\
\hline Condenser & $\begin{array}{l}\text { Tube-in-tube heat exchanger: Total length }=20 \mathrm{~m} \\
\text { Inner tube (copper tube type L): ID }=11.42 \mathrm{~mm} \\
\text { Outer tube (PVC): ID }=22 \mathrm{~mm}\end{array}$ \\
\hline Earth-tube heat exchanger & $\begin{array}{l}\text { Horizontal buried at } 0.5 \mathrm{~m}: \text { Total length }=65 \mathrm{~m} \\
\text { HDTE tube: ID }=16 \mathrm{~mm}\end{array}$ \\
\hline Fan coil unit & Econo Model YYK30-4/YYK30-4H \\
\hline Compressor & LGF Model QP306PAA \\
\hline Storage tank & Volume $=200 \mathrm{~L}$ \\
\hline
\end{tabular}

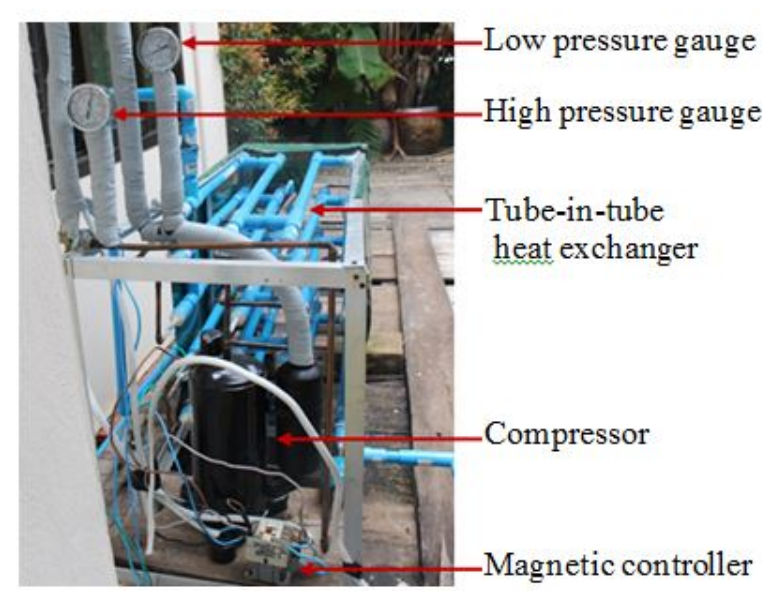

(a) Condensing unit

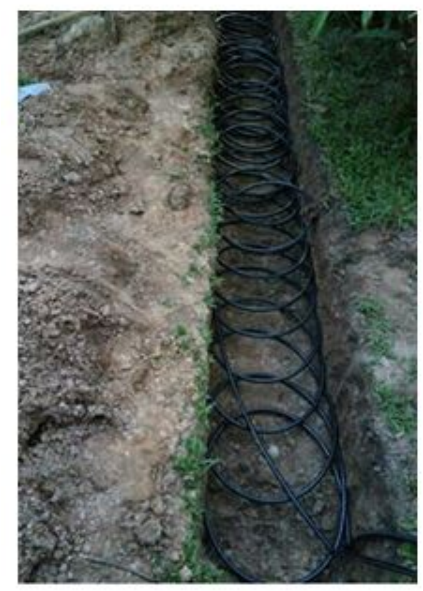

(c) Earth-tube heat exchanger

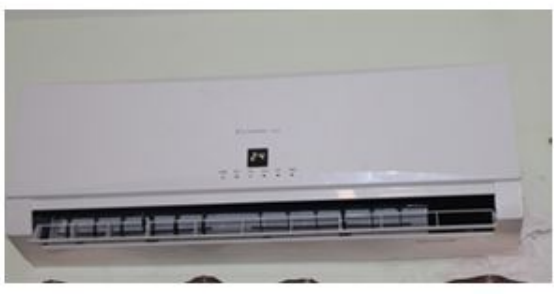

(b) Fan coil unit

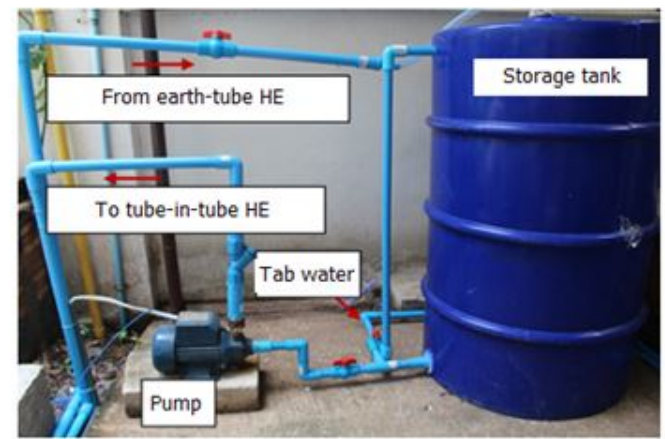

(d) Storage tank

Figure 2 The main components in the system. 


\section{Experiments and data reduction}

The measurement points of temperature $(\mathrm{T})$ and pressure $(\mathrm{P})$ for evaluating operation performance of the system are shown in Figure 3. Thermocouple type $\mathrm{K}$ was used for temperature measurement (T) of all positions as presented in Figure 3 with connection to the data logger for record. Pressure gages were used for measurement of refrigerant pressures and Rota flow meter was also used for measurement of water flow rate (see Figure 3). In addition, electric current and voltage supplied into the system were measured by the digital clamp meter. Details of instruments are presented in Table 3. Cooling mode and simultaneous cooling and heating mode were separately tested. For the test of cooling mode, the control valve at the line to user and at the tap line will be closed; on the other hand, simultaneous heating and cooling mode these 2 valves will be opened while other valves in water line will be closed. In the cooling mode test, the air temperature in the conditioned room was controlled by thermostat at $25^{\circ} \mathrm{C}$ and he water flow rate is constant at $6.0 \mathrm{~L} / \mathrm{min}$ while simultaneous heating and cooling mode the water flow rate will be varied by $2-6.8 \mathrm{~L} / \mathrm{min}$ (LPM). In the cooling mode, the measured data had been recorded every 5 minutes in $8 \mathrm{~h}$ for the daytime and in $9 \mathrm{~h}$ for the nighttime. The above data were used for evaluation of the system performance namely heat transfer rates in condenser, heat transfer rates in the earth-tube heat exchanger, COP of the HPS, the trends of inlet and outlet water temperatures of condenser, outlet water temperatures of the earth-tube heat exchanger, and the underground temperature at $0.5 \mathrm{~m}$ depth for cooling mode.

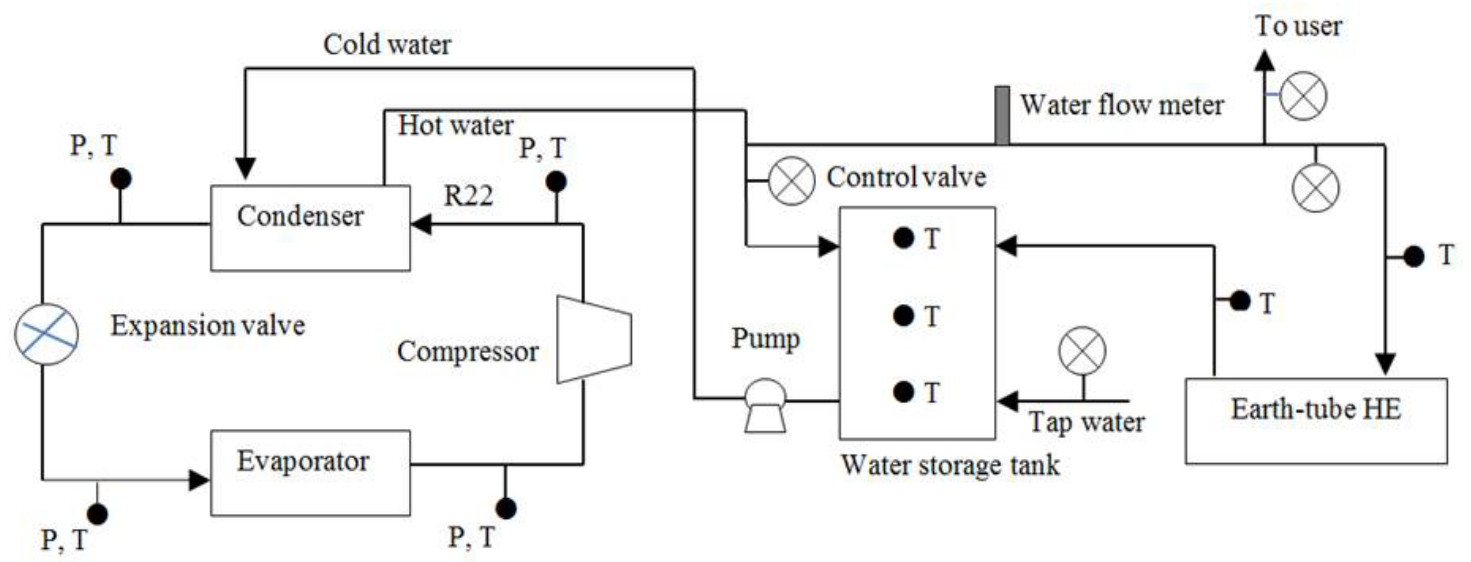

Figure 3 The positions of measurement for temperature, pressure and water flow rate.

Table 3 Details of the instruments.

\begin{tabular}{ccccc}
\hline Measurement & Devices & Model & Range & Uncertainty \\
\hline Temperature & Thermocouple & Type K & -25 to $150{ }^{\circ} \mathrm{C}$ & $\pm 0.5 \%$ \\
\hline Pressure & Pressure gauge & Okura & $0-250 \mathrm{~kg} / \mathrm{cm}^{2}$ & $\pm 0.10 \%$ \\
\hline Water flow rate & Rota flow meter & Dwyer RMC Series & 0 to $37 \mathrm{LPM}$ & $\pm 0.2 \%$ \\
\hline $\begin{array}{c}\text { AC current } \\
\text { AC voltage }\end{array}$ & Digital clamp meter & SUNWA 2017 & $\begin{array}{c}0 \text { to } 200 / 600 \mathrm{~A} \\
0 \text { to } 200 / 600 \mathrm{~V}\end{array}$ & $\begin{array}{c} \pm 1.5 \% \\
\pm 1 \%\end{array}$ \\
\hline
\end{tabular}




\section{Data reduction}

Heat transfer rate in the condenser $\left(\dot{Q}_{\text {cond }}\right)$ is calculated by the Eq. (16).

$\dot{\mathrm{Q}}_{\text {cond }}=\dot{\mathrm{m}}_{\mathrm{w}} \mathrm{c}_{\mathrm{pw}}\left(\mathrm{T}_{\mathrm{w}, \text { out,cond }} \mathrm{T}_{\mathrm{w}, \text { in, cond }}\right)$

where $\dot{\mathrm{m}}_{\mathrm{w}}$ is the mass flow rate of condenser $(\mathrm{kg} / \mathrm{s}), \mathrm{c}_{\mathrm{pw}}$ is the specific heat of water $\left(\mathrm{kJ} / \mathrm{kg}^{\circ} \mathrm{C}\right)$, $\mathrm{T}_{\mathrm{w}, \text { in,cond }}$ is the inlet water temperature of condenser $\left({ }^{\circ} \mathrm{C}\right)$ and $\mathrm{T}_{\mathrm{w}, \text { out,cond }}$ is the outlet water temperature of condenser $\left({ }^{\circ} \mathrm{C}\right)$.

Heat transfer rate in the earth-tube heat exchanger is calculated by the Eq. (17);

$$
\dot{\mathrm{Q}}_{\text {ethe }}=\dot{\mathrm{m}}_{\mathrm{w}} \mathrm{c}_{\mathrm{pw}}\left(\mathrm{T}_{\mathrm{w}, \text { out }, \text { ethe }}-\mathrm{T}_{\mathrm{w}, \text { in,ethe }}\right)
$$

where $T_{w, i n, e t h e}$ is the inlet water temperature of the earth-tube heat exchanger $\left({ }^{\circ} \mathrm{C}\right)$ and $\mathrm{T}_{\mathrm{w}, \text { out,ethe }}$ is the outlet water temperature of earth-tube heat exchanger $\left({ }^{\circ} \mathrm{C}\right)$.

The coefficient of performance for cooling mode $\left(\mathrm{COP}_{\text {cooling }}\right)$ and for simultaneous cooling and heating mode ( $\left.\mathrm{COP}_{\text {combiend }}\right)$ are determined by the Eq. (18) - (19), respectively.

$$
\begin{aligned}
& \mathrm{COP}_{\text {cooling }}=\frac{\dot{\mathrm{Q}}_{\mathrm{E}}}{\text { Total input electrical power }} \\
& \mathrm{COP}_{\text {combined }}=\frac{\dot{\mathrm{Q}}_{\mathrm{E}}+\dot{\mathrm{Q}}_{\text {cond }}}{\text { Total input electrical power }}
\end{aligned}
$$

where $\dot{Q}_{E}$ is the heat transfer rate in the evaporator $(\mathrm{kW})$.

For heat transfer rate in the evaporator is calculated by the Eq. (20).

$\dot{\mathrm{Q}}_{\mathrm{E}}=\dot{\mathrm{m}}_{\mathrm{r}}\left(\mathrm{h}_{\mathrm{r}, \text { out }, \mathrm{E}}-\mathrm{h}_{\mathrm{r}, \text { out }, \mathrm{C}}\right)$

where $\dot{\mathrm{m}}_{\mathrm{r}}$ is refrigerant mass flow rate $(\mathrm{kg} / \mathrm{s}), \mathrm{h}_{\mathrm{r}, \text { out,E}}$ is outlet refrigerant enthalpy of the evaporator $(\mathrm{kJ} / \mathrm{kg})$, and $\mathrm{h}_{\mathrm{r}, \text { out }, \mathrm{C}}$ is outlet refrigerant enthalpy of the condenser $(\mathrm{kJ} / \mathrm{kg})$. is;

The refrigerant mass flow rate is figured out by heat balance equation in the condenser. The result

$\dot{\mathrm{m}}_{\mathrm{r}}=\frac{\dot{\mathrm{Q}}_{\text {cond }}}{\mathrm{h}_{\mathrm{r}, \text { in }, \mathrm{C}}-\mathrm{h}_{\mathrm{r}, \text { out }, \mathrm{C}}}$

where $h_{r, i n, C}$ is inlet refrigerant enthalpy of the condenser $(\mathrm{kJ} / \mathrm{kg})$, and $h_{r, o u t, C}$ is outlet refrigerant enthalpy of the condenser $(\mathrm{kJ} / \mathrm{kg})$.

\section{Uncertainty analysis}

As a function of measurement accuracy, an error analysis must be made on the heat transfer rates in the condenser and in the earth-tube heat exchanger by a propagation-of-error method [17]. The results of uncertainty of heat transfer rates in condenser $\left(\Delta \omega_{\dot{\mathrm{Q}}_{C}}\right)$ and in the ETHE $\left(\Delta \omega_{\dot{\mathrm{Q}}_{\text {ethe }}}\right)$ are calculated by the Eqs. (22) - (23), respectively.

$$
\begin{aligned}
& \Delta \omega_{\dot{\mathrm{Q}}_{\text {cond }}}=\sqrt{\left(\frac{\partial \dot{\mathrm{Q}}_{\text {cond }}}{\partial \dot{\mathrm{m}}_{\mathrm{w}}} \cdot \Delta \omega_{\dot{\mathrm{m}}_{\mathrm{w}}}\right)^{2}+\left(\frac{\partial \dot{\mathrm{Q}}_{\text {cond }}}{\partial \mathrm{T}_{\mathrm{w}, \text { out,cond }}} \cdot \Delta \omega_{\mathrm{T}_{\mathrm{w}, \text { out,cond }}}\right)^{2}+\left(\frac{\partial \dot{\mathrm{Q}}_{\text {cond }}}{\partial \mathrm{T}_{\mathrm{w}, \text { in, ond }}} \cdot \Delta \omega_{\mathrm{T}_{\mathrm{w}, \text { in, cond }}}\right)^{2}} \\
& \Delta \omega_{\dot{\mathrm{Q}}_{\text {ethe }}}=\sqrt{\left(\frac{\partial \dot{\mathrm{Q}}_{\text {ethe }}}{\partial \dot{\mathrm{m}}_{\mathrm{w}}} \cdot \Delta \omega_{\dot{\mathrm{m}}_{\mathrm{w}}}\right)^{2}+\left(\frac{\partial \dot{\mathrm{Q}}_{\text {ethe }}}{\partial \mathrm{T}_{\mathrm{w}, \text { outethe }}} \cdot \Delta \omega_{\mathrm{T}_{\mathrm{w}, \text { out ethe }}}\right)^{2}+\left(\frac{\partial \dot{\mathrm{Q}}_{\text {ethe }}}{\partial \mathrm{T}_{\mathrm{w}, \text { in,ethe }}} \cdot \Delta \omega_{\mathrm{T}_{\mathrm{w}, \mathrm{in}, \text { ethe }}}\right)^{2}}
\end{aligned}
$$


or written in the form of percentage of uncertainty as:

$\% \Delta \omega_{\dot{Q}_{\text {cond }}}=\frac{\Delta \omega_{\dot{Q}_{\text {cond }}}}{\dot{\mathrm{Q}}_{\text {cond }}} \times 100$

$\% \Delta \omega_{\dot{Q}_{\text {ethe }}}=\frac{\Delta \omega_{\dot{Q}_{\text {ethe }}}}{\dot{\mathrm{Q}}_{\text {ethe }}} \times 100$

where $\Delta \omega_{\dot{\mathrm{m}}_{\mathrm{w}}}$ is uncertainties in measurement of the water flow rate $( \pm \mathrm{kg} / \mathrm{s}), \Delta \omega_{\mathrm{T}_{\mathrm{w}, \text { out,cond }}}$ is uncertainty in measurement of the outlet water temperature of condenser $\left( \pm^{\circ} \mathrm{C}\right), \Delta \omega_{\mathrm{T}_{\mathrm{w}, \text { in, cond }}}$ is uncertainty in measurement of the inlet water temperature of condenser $\left( \pm^{\circ} \mathrm{C}\right), \Delta \omega_{\mathrm{T}_{\mathrm{w}, \text { out,ethe }}}$ is uncertainty in measurement of the outlet water temperature of the ETHE $\left( \pm^{\circ} \mathrm{C}\right)$, and $\Delta \omega_{\mathrm{T}_{\mathrm{w}, \text { in,ethe }}}$ is uncertainty in measurement of the inlet water temperature of the $\operatorname{ETHE}\left( \pm^{\circ} \mathrm{C}\right)$.

In addition, uncertainty of coefficients of performance in both cooling mode $\left(\Delta \omega_{\mathrm{CO}} P_{\text {coling }}\right)$ and in simultaneous cooling and heating mode $\left(\Delta \omega_{\mathrm{COP}}{ }_{\text {combined }}\right)$ are calculated by the Eqs. (26) - (27), respectively.

$\Delta \omega_{\mathrm{COP}_{\text {cooling }}}=\sqrt{\left(\frac{\partial \mathrm{COP}_{\text {cooling }}}{\partial \mathrm{Q}_{\mathrm{E}}} \cdot \Delta \omega_{\mathrm{Q}_{\mathrm{E}}}\right)^{2}+\left(\frac{\partial \mathrm{COP}_{\text {cooling }}}{\partial \mathrm{EP}} \cdot \Delta \omega_{\mathrm{EP}}\right)^{2}}$

$\Delta \omega_{\mathrm{COP}_{\text {combined }}}=\sqrt{\left(\frac{\partial \mathrm{COP}_{\text {combined }}}{\partial \mathrm{Q}_{\mathrm{E}}} \cdot \Delta \omega_{\mathrm{Q}_{\mathrm{E}}}\right)^{2}+\left(\frac{\partial \mathrm{COP} \mathrm{P}_{\text {combined }}}{\partial \mathrm{Q}_{\text {cond }}} \cdot \Delta \omega_{\dot{\mathrm{Q}}_{\text {cond }}}\right)^{2}+\left(\frac{\partial \mathrm{COP}}{\partial \mathrm{EP}}{ }_{\text {combind }} \cdot \Delta \omega_{\mathrm{EP}}\right)^{2}}$

or written in the form of percentage of uncertainty as:

$$
\begin{aligned}
\% \Delta \omega_{\mathrm{COP}} \text { cooling } & =\frac{\Delta \omega_{\mathrm{COP}} \text { cooling }}{C O P_{\text {cooling }}} \times 100 \\
\% \Delta \omega_{\mathrm{COP}} \text { combined } & =\frac{\Delta \omega_{\text {COP }} \text { combined }}{C O P_{\text {combined }}} \times 100
\end{aligned}
$$

where $\Delta \omega_{\mathrm{EP}}$ is the uncertainty of total electrical power $( \pm \mathrm{kW}), \Delta \omega_{\mathrm{Q}_{\mathrm{E}}}$ is the uncertainty of heat transfer rate in the evaporator $( \pm \mathrm{kW})$.

As the total electrical power determined by the electric power equation; therefore, the uncertainty of the total electrical power $\left(\Delta \omega_{\mathrm{EP}}\right)$ is calculated by the Eq. (30);

$\Delta \omega_{\mathrm{EP}}=\sqrt{\left(\frac{\partial \mathrm{EP}}{\partial \mathrm{I}} \cdot \Delta \omega_{\mathrm{I}}\right)^{2}+\left(\frac{\partial \mathrm{EP}}{\partial \mathrm{V}} \cdot \Delta \omega_{\mathrm{V}}\right)^{2}}$

where $\Delta \omega_{\mathrm{I}}$ and $\Delta \omega_{\mathrm{V}}$ are uncertainties in measurement of electric current and voltage, respectively.

For uncertainty of heat transfer rate in the evaporator $\left(\Delta \omega_{\dot{\mathrm{Q}}_{\mathrm{E}}}\right)$ is determined by the Eq. (31);

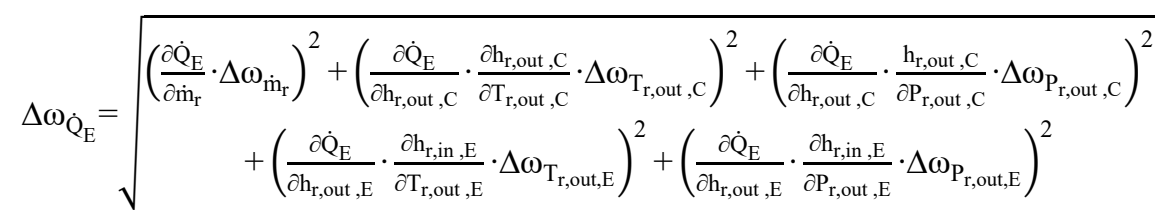

or written in the form of percentage of uncertainty as:

$$
\% \Delta \omega_{\dot{\mathrm{Q}}_{\mathrm{E}}}=\frac{\Delta \omega_{\dot{\mathrm{Q}}_{\mathrm{E}}}}{\dot{\mathrm{Q}}_{\mathrm{E}}} \times 100
$$


Uncertainty of refrigerant mass flow rate $\left(\Delta \omega_{\dot{\mathrm{m}}_{\mathrm{r}}}\right)$ is calculated by the Eq. (33);

$\Delta \omega_{\dot{\mathrm{m}}_{\mathrm{r}}}=\sqrt{\begin{array}{c}\left(\frac{\partial \dot{\mathrm{m}}_{\mathrm{r}}}{\partial \dot{\mathrm{Q}}_{\mathrm{C}}} \cdot \Delta \omega_{\mathrm{Q}_{\mathrm{C}}}\right)^{2}+\left(\frac{\partial \dot{\mathrm{m}}_{\mathrm{r}}}{\partial \mathrm{h}_{\mathrm{r}, \text { out }, \mathrm{C}}} \cdot \frac{\partial \mathrm{h}_{\mathrm{r}, \text { out }, \mathrm{C}}}{\partial \mathrm{T}_{\mathrm{r}, \text { out }, \mathrm{C}}} \cdot \Delta \omega_{\mathrm{T}_{\mathrm{r}, \text { out }, \mathrm{C}}}\right)^{2}+\left(\frac{\partial \dot{\mathrm{m}}_{\mathrm{r}}}{\partial \mathrm{h}_{\mathrm{r}, \text { out }, \mathrm{C}}} \cdot \frac{\mathrm{h}_{\mathrm{r}, \text { out }, \mathrm{C}}}{\partial \mathrm{P}_{\mathrm{r}, \text { out }, \mathrm{C}}} \cdot \Delta \omega_{\mathrm{P}_{\mathrm{r}, \text { out }, \mathrm{C}}}\right)^{2} \\ +\left(\frac{\partial \dot{\mathrm{m}}_{\mathrm{r}}}{\partial \mathrm{h}_{\mathrm{r}, \mathrm{in}, \mathrm{C}}} \cdot \frac{\partial \mathrm{h}_{\mathrm{r}, \mathrm{in}, \mathrm{C}}}{\partial \mathrm{T}_{\mathrm{r}, \mathrm{in}, \mathrm{C}}} \cdot \Delta \omega_{\mathrm{T}_{\mathrm{r}, \text { in }, \mathrm{C}}}\right)^{2}+\left(\frac{\partial \dot{\mathrm{m}}_{\mathrm{r}}}{\partial \mathrm{h}_{\mathrm{r}, \mathrm{in}, \mathrm{C}}} \cdot \frac{\mathrm{h}_{\mathrm{r}, \text { in }, \mathrm{C}}}{\partial \mathrm{P}_{\mathrm{r}, \mathrm{in}, \mathrm{C}}} \cdot \Delta \omega_{\mathrm{P}_{\mathrm{r}, \text { in }, \mathrm{C}}}\right)^{2}\end{array}}$

where $\Delta \omega_{\mathrm{T}_{\mathrm{r}, \text { out }, \mathrm{C}}}$ is uncertainty of the outlet refrigerant temperature of condenser $\left( \pm^{\circ} \mathrm{C}\right), \Delta \omega_{\mathrm{T}_{\mathrm{r}, \text {, }, \mathrm{C}}}$ is uncertainty in measurement of the inlet refrigerant temperature of condenser $\left( \pm^{\circ} \mathrm{C}\right), \Delta \omega_{\mathrm{P}_{\mathrm{r}, \text { out }} \mathrm{C}}$ is uncertainty in measurement of the outlet refrigerant pressure of condenser $( \pm \mathrm{kPa}), \Delta \omega_{\mathrm{P}_{\mathrm{r}, \mathrm{in}, \mathrm{C}}}$ is uncertainty in measurement of the inlet refrigerant pressure of condenser $( \pm \mathrm{kPa})$.

Enthalpies of the refrigerant in the above equations are a function of pressure and temperature (in vapor phase or in liquid phase) which are calculated by the equation of states for R22 refrigerant [18].

\section{Results and discussion}

\section{Cooling mode}

The system had been tested for evaluating performance of the system with setting $25{ }^{\circ} \mathrm{C}$ in the thermostat. Inlet and outlet water temperatures at the condenser, outlet water temperature from the earth tube-to-water heat exchanger (ETHE) and the soil temperature were measured for operating in the daytime and the night time resulting in Figures $\mathbf{4}$ and 5, respectively. It was shown that the soil temperature at $0.5 \mathrm{~m}$ depth was almost constant for both daytime and nighttime approximately $31^{\circ} \mathrm{C}$ (in this case, ground surface above the ETHE was covered by the grass). The inlet and outlet water temperatures of condenser and outlet water temperature from the ETHE were slightly increased for daytime operation (Figure 4) because heat gain from solar will be influent to the conditioned room. This effects will increase the heat load in the room resulting the air-conditioner will run longer time in order to condition air in the room to be temperature requirement. At the beginning (see Figure 4) the airconditioner is able to condition air to be temperature requirement (see temperature dropped sharply) but after that the air-conditioner cannot condition air to be in the requirement and the water temperatures will be increased all measured positions in the cooling system until the water in the storage tank will partly drained out in which the tap water will flow into the tank for recovering. For nighttime, in the other hand, as solar effect does not induce to increasing heat load, the air-conditioner is capable to condition air in the room to be in the requirement throughout the nighttime (see Figure 5). It runs longer time in order to be in the requirement temperature only in the beginning because it must cool heat which is collected in the room due to solar effect before entering to the nighttime. In addition, heat transfer rates in condenser and in the ETHE had been calculated by the Eqs. (19) - (20), respectively for both daytime and nighttime with constant water flow rate of $6.0 \mathrm{~L} / \mathrm{min}$. It was found that heat transfer rates in condenser are higher than in the ETHE. For daytime, in the beginning of working the heat transfer rates for both in condenser and in the ETHE are absolutely high and after that time the heat transfer rate will be slightly declined and then be almost constant at approximately $5.8 \mathrm{~kW}$ (mean uncertainty of $\pm 3.62 \%$ ) and $4 \mathrm{~kW}$ (mean uncertainty of $\pm 3.56 \%$ ) for condenser and ETHE, respectively. For nighttime, in the other hand, the system is able to run with high heat transfer rates for longer time and it was found that a duration of the constant heat transfer rates, heat transfer rate of condenser is similar to that in the daytime but heat transfer rate in the ETHE is higher than that in the daytime resulting lower water temperature in the storage tank when the system was shut off. Summary of system performances in cooling mode are presented in Table $\mathbf{4}$ and electrical consumption in the system was also presented in Table 5.

See the summarized performances in the cooling mode above, it showed that the coefficients of performance are satisfactory only in the nighttime if the COP of this system is higher than the COP of the air-to-air heat pump which normally is about 3 to 3.5. By contrast, in the daytime, COP of the system for cooling mode is still lower than the air-to-air heat pump but this can be improved by adjusting an increase of temperature set in thermostat. It can be shown that when the temperature set is adjusted from $25^{\circ} \mathrm{C}$ to $27^{\circ} \mathrm{C}$, the electrical consumption in the system can be reduced by about $12 \%$ in the daytime and $45 \%$ in the nighttime as shown in Table 5. In addition, another benefit is to use the hot water stored in the tank to directly consume for residences after shutting off the system.

As the above results, uncertainty level of the $\mathrm{COP}_{\text {cooling }}$ is high because mass flow rates of the refrigerant were figured out by the heat balance in the condenser. The performance of the HPS is still low 
when it works in the cooling mode for the daytime because the soil temperature at the position of the ETHE installed is not low enough. In practical applications for engineers, nanofluids are primarily used for their enhanced thermal properties as coolants in heat exchangers resulted in reduction in size of heat exchanger and in pumping power. A useful research on nanofluids for heating and cooling processes in an improved heat exchanger is proposed by Faroogh et al. [19]. Therefore, a position of the installation of the ETHE and a nanofluid application as external or secondary heat sink for the HPS will be focused in the next research.

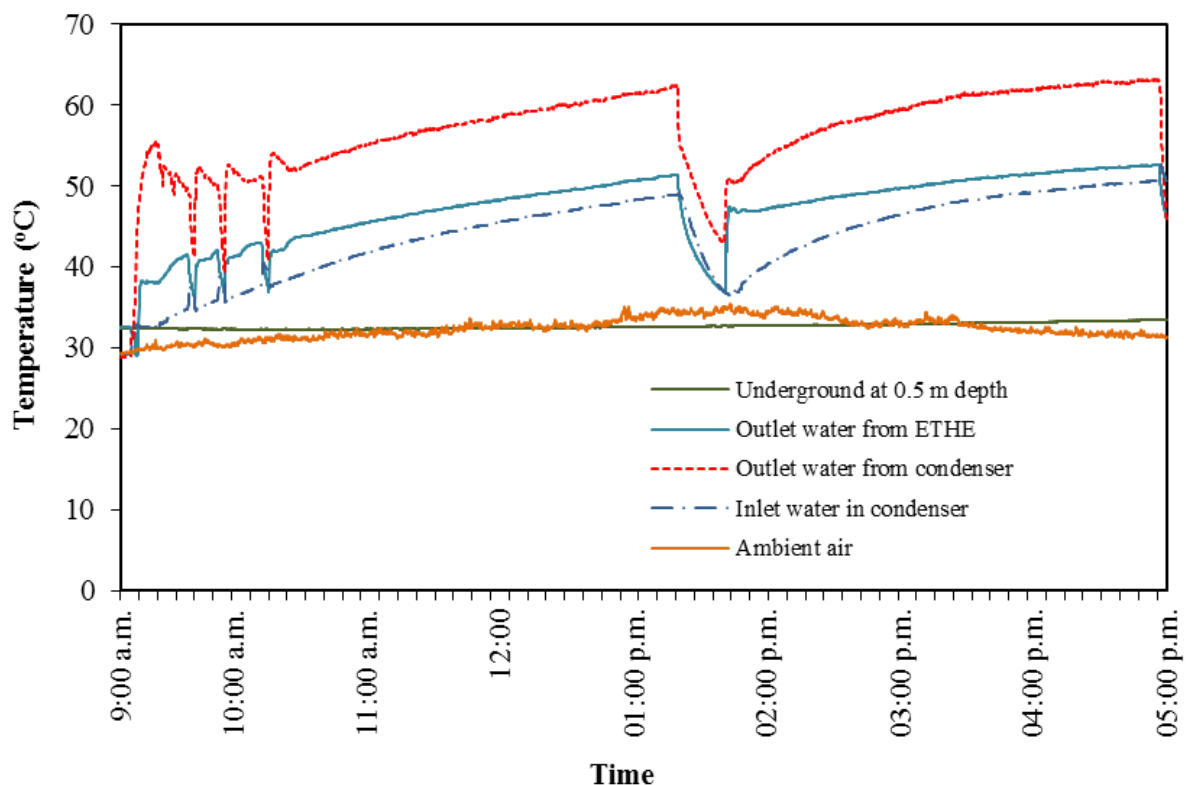

Figure 4 The trends of measured temperatures in the system for daytime (recorded on September 3, 2019).

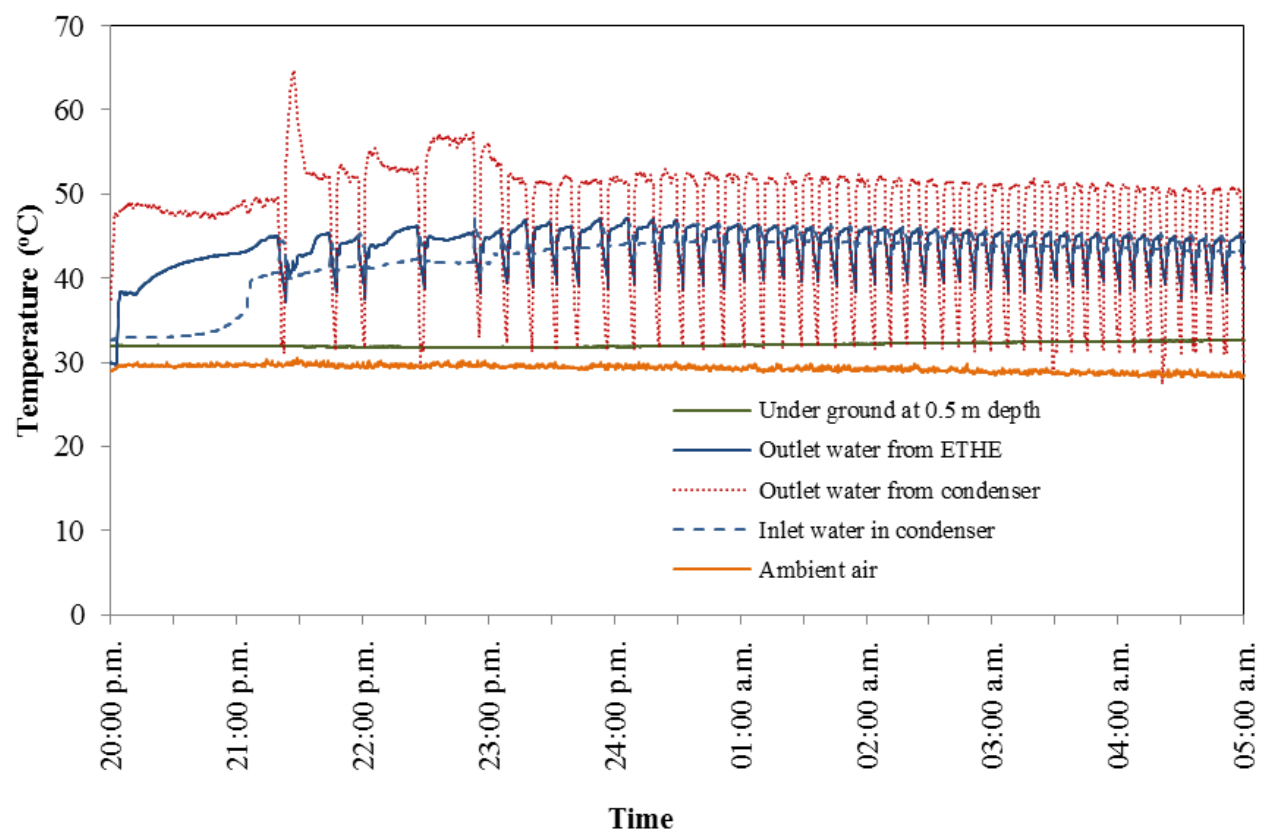

Figure 5 The trends of measured temperatures in the system for nighttime (recorded on September 3, 2019). 
Table 4 Performances in cooling mode at setting $25^{\circ} \mathrm{C}$ in thermostat.

\begin{tabular}{llcc}
\hline \multicolumn{1}{c}{ Indexes } & Daytime & Nighttime & Uncertainty \\
\hline COP & 2.4 to 2.5 & 3 to 5.6 & $\pm 14.5 \%$ \\
Cooling capacity in condenser & 5.8 to $6 \mathrm{~kW}$ & 6 to $9.5 \mathrm{~kW}$ & $\pm 3.6 \%$ \\
Cooling capacity in ETHE & 4 to $5 \mathrm{~kW}$ & 5 to $7 \mathrm{~kW}$ & $\pm 3.5 \%$ \\
Water temperature in the tank after shut off & $45^{\circ} \mathrm{C}$ & $40{ }^{\circ} \mathrm{C}$ & $\pm 0.5 \%$ \\
\hline
\end{tabular}

Table 5 The electrical energy consumption in the system for cooling mode.

\begin{tabular}{cccc}
\hline Temperature set & Daytime & Nighttime & Uncertainty \\
\hline $25{ }^{\circ} \mathrm{C}$ & $1.7 \mathrm{kWhr} / \mathrm{h}$ & $1.45 \mathrm{kWhr} / \mathrm{h}$ & $\pm 1.8 \%$ \\
$27{ }^{\circ} \mathrm{C}$ & $1.5 \mathrm{kWhr} / \mathrm{h}$ & $0.8 \mathrm{kWhr} / \mathrm{h}$ & $\pm 1.8 \%$ \\
\hline
\end{tabular}

\section{Simultaneous heating and cooling mode}

In addition to cooling mode, an evaluation of the system running in simultaneous heating and cooling mode (produce hot water with one-pass heating to supply consumers and cooling space at the same time) in which the tap water will supply to condenser without cooling in ETHE and the hot water produced by condenser will then supply to user. The experimental results are shown in Table 6. It was found that optimal water flow rate which is able to produce hot water in suitable temperature for using in the residences is $6 \mathrm{~L} / \mathrm{min}$ with the system COP of $6.3 \pm 3.1 \%$.

Table 6 Performance of the system running in cooling and heating mode.

\begin{tabular}{ccccc}
\hline $\begin{array}{c}\text { Water flow rate } \\
(\mathbf{L} / \mathbf{m i n})\end{array}$ & $\begin{array}{c}\text { Tap water } \\
\text { temperature } \\
\left({ }^{\circ} \mathbf{C}\right)\end{array}$ & $\begin{array}{c}\text { Hot water } \\
\text { temperature } \\
\left({ }^{\circ} \mathbf{C}\right)\end{array}$ & $\mathbf{C O P}_{\text {combined }}$ & Uncertainty \\
\hline 6.8 & 30.8 & 34.5 & 10.4 & $\pm 3.0 \%$ \\
6 & 30.9 & 40.2 & 6.3 & $\pm 3.1 \%$ \\
2 & 31.1 & 50.9 & 5.4 & $\pm 3.1 \%$ \\
\hline
\end{tabular}

\section{Conclusions}

A HPS was designed for 2 operating modes: Cooling mode (air-conditioning) and simultaneous heating (hot water production) and cooling (air-conditioning) mode for Thai residences. For operating in cooling mode, a shallow horizontally earth-tube heat exchanger will be used as a secondary heat sink and its working showed that it can operate with higher COP than traditional air-conditioner (air-to-air heat pump) only in the nighttime. It can continuously operate with almost high COP in nighttime about $5.0 \pm 14.5 \%$; however, its performance will be degraded if the conditioned room is affected by the solar radiation in the daytime but this can be improved by an increase of temperature set in thermostat. Fortunately, for simultaneous heating and cooling mode the system showed very high COP approximately $6.3 \pm 3.1 \%$. This means that this system is possible to replace both the traditional air-conditioner and electrical water heater for energy saving in Thai residences.

\section{Acknowledgements}

The work partially funded by the Division of Research Supporting and Extension Services, Mahasarakham University, Thailand. 


\section{References}

[1] Energy Policy and Planning Office. Report of the energy statics of Thailand (in Thai). Energy Policy and Planning Office, Ministry of Energy, Bangkok, Thailand, 2019.

[2] K Poolsawat, W Tachajapong, S Prasitwattanaseree and W Wongsapai. Electricity consumption characteristics in Thailand residential sector and its saving potential. In: Proceeding of the $6^{\text {th }}$ International Conference on Power and Energy Systems Engineering, Okinawa, Japan. 2019, p. $337-43$

[3] W Arunwattana. 2000, Improvement of condenser with evaporative cooling (in Thai). Master Thesis. King Mongkut's University of Technology Thonburi, Bangkok, Thailand.

[4] W Arunwattana, P Audtamasoon and A Rawadchoo. Triple state system decreases the cooling load of an evaporative cooling system (in Thai). MSU J. Sci. Tech. 2009; 28, 137-42.

[5] W Arunwattana. The decrease of cooling load in the vapor compression system by the earth-to-air heat exchanger system. Suranaree J. Sci. Tech. 2008; 15, 45-55.

[6] P Congedo, C Baglivo, S Bonuso and D Agostino. Numerical and experimental analysis of the energy performance of an air-source heat pump (ASHP) coupled with a horizontal earth-to-air heat exchanger (EAHX) in different climates. Geothemics 2020; 87, 101845.

[7] A Siricharoenpanich, S Wiriyasart, R Prurapark and P Naphon. Effect of cooling water loop on the thermal performance of air conditioning system. Case Stud. Therm. Eng. 2019; 15, 100518.

[8] S Juengjaroennirachon, N Pratinthong, P Namprakai and T Suparos. Performance enhancement of air conditionin using thermosyphon system's energy storage unit for cooling refrigerant before entering the condenser. J. Mech. Sci. Tech. 2016; 31, 393-400.

[9] L Ni, J Dong, Y Yao, C Shen, D Qv and X Zhang. A review of heat pump systems for heating and cooling of buildings in China in the last decade. Renew. Energ. 2015; 84, 30-45.

[10] JJ Tomlinson, CK Rice and E Baskin. Integrated heat pumps for combined space conditioning and water heating. In: Proceeding of the $8^{\text {th }}$ IEA Heat Pump Conference, Las Vegas, United State. 2005.

[11] P Byrne and A Diaby. Simulation study of a heat pump for simultaneous heating and cooling coupled to buildings. Energ. Build. 2014; 72, 141-9.

[12] M Pinamonti and P Baggio. Energy and economic optimization of solar-assisted heat pump systems with storage technologies for heating and cooling in residential buildings. Renew. Energ. 2020; 157, 90-9.

[13] S Bertagnolio and P Staba. Review of heat recovery and heat pumping solutions. AECOM, St Albans, England, 2011.

[14] BS Petukhov. Heat transfer and friction in turbulent pipe flow with variable physical properties. Adv. Heat Trans. 1970; 6, 503-64.

[15] V Gnielinski. New equation for heat and mass transfer in turbulent pipe and channel flow. Int. Chem. Eng. 1976; 16, 359-68.

[16] MK Dobson and JC Chato. Condensation in smooth horizontal tubes. J. Heat Trans. 1998; 120, 193-213.

[17] JP Holman. Experimental methods for engineers. $8^{\text {th }}$ ed. McGraw-Hill, New York, 2012, p. 63.

[18] W Wagner, V Marx and A Prob. A new equation of state for chlorodifluoromethane covering the entire fluid region from $116 \mathrm{~K}$ to $550 \mathrm{~K}$ at pressures up to $200 \mathrm{MPa}$. Int. J. Refrig. 1993; 16, 373.

[19] G Faroogh, H Faraz and MR Mohammad. Numerical study of heat transfer performance of nanofluids in a heat exchanger. Appl. Therm. Eng. 2016; 105, 435-55. 